\title{
Indonesian traveler study: analyze the role of the big five personalities on hard adventure traveler type
}

Lusy Asa Akhrani ${ }^{1 *}$, Chintya Fatima Dewi ${ }^{2}$

Department of Psychology, Universitas Brawijaya, Malang, Indonesia ${ }^{1 *, 2}$

$\underline{\text { lusyasa@ub.ac.id }}$

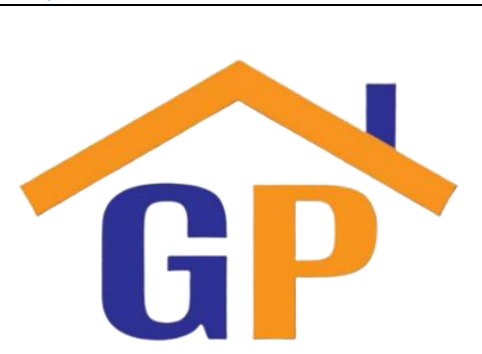

Article History

Received on 4 January 2021

$1^{\text {st }}$ Revision on 18 January 2021

$2^{\text {nd }}$ Revision on 22 January 2021

$3^{\text {rd }}$ Revision on 1 June 2021

Accepted on 2 June 2021

\begin{abstract}
Purpose: This study aims to determine the role of big five personalities simultaneously and partially towards the tendency of
\end{abstract} hard adventure travelers.

Research methodology: This study will also look at the five traits found in the big five personalities which tend to play a role in the hard adventure traveler. This research is a replication study of Kristin Scott and John C. Mowen with a quantitative approach involving 1,558 subjects with a purposive sampling technique. Big five personality was measured using the big five infentory scale, while the hard adventure type would be measured using a scale from Scott \& Mowen. Data analysis of this study using multiple regression techniques.

Results: The results showed that there is a role of big five personalities that is simultaneous towards traveler's hard adventure type of $7,6 \%$, whereas partially openness, extraversion, and neuroticism trait had a role towards the type of hard adventure, where openness trait had the biggest role towards hard adventure type.

Limitations: Based on the magnitude of the role generated in this study, there are still other factors that can influence traveler's decision making to choose the traveling type, so that these other factors are expected to explore more.

Contribution: This research can be a reference in the development of tourist attraction marketing by taking into account visitors' personality types.

Keywords: Big 5 personalities, Hard adventure, Traveling type

How to cite: Akhrani, L. A., \& Dewi, C. F. (2020). Indonesian traveler study: analyze the role of big five personalities on hard adventure traveler type. Journal of Sustainable Tourism and Entrepreneurship, 2(2), 83-94.

\section{Introduction}

Traveling is no longer a tertiary or secondary need but has shifted to a primary need, where traveling is not just a short trip. Still, individuals now need to travel more often and more prolonged (Kurniawan, 2015). According to Harianto Gunawan, Director of Visa Indonesia, in his interview with Neraca Economic Daily, there are many reasons people go on vacation. Including wanting to spend time with family, doing cultural tours, adventure, pampering, and relaxing, so many reasons why people want to go on vacation.

Nature tourism is now increasingly in demand from the archipelago and foreign countries (Pertiwi, 2011). The trip was more dominated by young people from Indonesia. One type of nature tourism often in demand by individual and group travelers is white water rafting. Challenging tourism with a high enough risk tends to be dominated by travelers at a young age, given the amount of risk they have. 
Knowing the various types of travel is an important thing to do in developing tourist attractions as mentioned above. This becomes important because in managing a tourist spot, knowing the tour type allows the manager to provide the maximum variety of needs needed by a traveler. There are various types of trips, according to Scott \& Mowen (2007), which models of trips grouped into four, namely hard adventure, soft adventure, luxury travel, and camping travel.

Hard adventure and soft adventure are divisions of the type of travel adventure. The adventure was defined as an activity deliberately carried out by a traveler with risks and uncertain outcomes. The attraction of outdoor activities relies on natural terrain and requires special tools (Ewert, 1987). Tours such as sky-diving and white-water rafting that require natural terrain with high risks are tours that fall into the type of hard adventure. The hard adventure was defined as a journey to gain extreme experience with a high potential risk level in the external environment (Scott \& Mowen, 2007). Tourism with this type of travel tends to be attractive to young people; challenging high risk is one reason. The higher the risk for these types of tours, the traveler will be more challenged to do so. Knowing various types of trips is a crucial thing to do in developing tourist attractions. This becomes important because in managing a tourist destination so that the tour makes the manager can provide a variety of needs needed by the traveler to the maximum, especially for the type of trip that has a high risk as in this type of hard adventure. The type of hard travel traveler is a little different from other types of travel. In the type of hard travel, a travel activity usually requires extra equipment and security; besides, this type of traveler has different needs on travel.

\section{Literature review}

\subsection{Big five personalities}

Personality has been an issue that experts have studied since the late 1920s. Some experts try to define personality based on the results of each research, including Allport (Corr \& Matthews, 2009), which defines personality as a dynamic organization in a person who is a psychopathic system and determines how an individual adjusts to personality the environment. Personality is also a relatively fixed pattern, trait, disposition, or characteristics in individuals that show consistency in behavior (Feist \& Feist, 2009). Another figure argues that the definition of personality is Cattel, who uses a trait to predict behavior. Personality is defined as predicting what someone will do in a particular situation and then defining personality traits as something that determines what someone will do when confronted with the situation determined (Corr \& Matthews, 2009).

Differences in opinion about personality are not only related to the definition of personality but also about the types of traits that make up a person's personality. One opinion that uses the widely used trait approach is the theory of five-factor personality or the big five personalities. McCrae \& Costa in Pervin, Cervone, \& John, (2010) defines big five personalities as an individual personality that formed in five personality domains that have been formed using factor analysis. Feist and Feist (2009) state that the big five is a personality that can both predict and explain behavior. Scott and Mowen (2007), with their research entitled "Travelers and their trait: Ahierarchical model approach," states that differences in the motivational network of traits in individuals will show different results on the type of travel interest they do. Trait differences in each type of trip also affect the communication strategy undertaken to capture the traveler.

Research on the Big Five shows that trait is a consistent predictor in a variety of situations, especially in this case is traveling behavior. According to Weiten (Wulandari \& Rehulina, 2013), personality is the uniqueness of individuals' inconsistent behavioral traits. Feist \& Feist (2009) said that nature is individual differences in behavior and is consistent in their behavior from time to time and in dealing with various situations.

McCrae \& Costa in Pervin, Cervone, \& John, (2010) defines the Big Five Personality as individual personalities which were arranged in five personality domains that have been formed using factor analysis (Pervin, Cervone, \& John, 2010). McCrae \& Costa in Pervin, Cervone, \& John, (2010) mention that the five traits in the big five personalities are extraversion (E), agreeableness (A), conscientiousness 
$(\mathrm{C})$, neuroticism $(\mathrm{N})$, and openness to experiences $(\mathrm{O})$. Each individual is described as having five Big Five traits but has a tendency to one particular trait (Friedman \& Schustack, 2006).

Table 1. Definition and Guidelines for the Big 5 Personality Theory

\begin{tabular}{l}
\hline \multicolumn{1}{c}{ Theory Definition and Guidelines } \\
\hline Openness \\
\hline High Score: Curiosity, Interest/relevance that is varied, Independent \\
Low Score: Practical, Conventional, Choosing Routines \\
\hline Conscientiousness \\
\hline High Score: Hardworking, Reliable, Organized \\
Low Score: Impulsive, Careless, Disorganized \\
\hline Extraversion \\
\hline High Score: Outgoing, Looking for Adventure \\
Low Score: Quiet, Quiet, Withdrawing \\
\hline Agreeableness \\
\hline High Score: Happy to help, Easy to believe \\
Low Score: Critical, Not Cooperative, Suspicious \\
\hline Neuroticism \\
\hline High Score: Anxious, Unhappy, Vulnerable to negative emotions \\
Low Score: Calm down, Complete self, Safe
\end{tabular}

Trait itself is often linked in various aspects of life, as in research conducted by Jani (2014), where professional tourism managers can use the Big Five Personality to market and design their tourism products more attractive and satisfying for each tourist with a different personality. Research on Big Five Personality with various types of travel has not been done much, especially in Indonesia. Seeing the interest of the Indonesian people towards the need for travel is increasing, and the lack of individual ability to choose the type of travel that suits their abilities.

\subsection{Hard adventure}

Travel tours have several types, including hard adventure. Hard adventure travel is defined as a journey to gain the ultimate experience with a high level of potential risk in the external environment (Scott \& Mowen, 2007). Hard Adventure refers to activities associated with a high level of risk, where a traveler must meet specified conditions if he wants to participate in these activities, such as being physically and mentally healthy (Mill, 2010). Hill (Swarbrooke, Beard, Leckie, \& Pomfret, 2003) also said that hard adventure is an activity with a high level of risk, requires intense commitment and skills. A traveler who travels on this type tends to engage in external activities that are physically and mentally challenging. This activity is also more likely to be carried out by someone who has a high level of competence.

The risk borne by the traveler depends on the experience possessed by each traveler because experience plays an important role in the participation of the traveler in carrying out activities that are in the type of hard adventure. Lipscombe (Swarbrooke, Beard, Leckie, \& Pomfret, 2003) said that the elements of challenge, danger, and risk are things that contribute to the development of hard adventure. The traveler will be more motivated when they know that the risk in the activity is getting higher, and along with their experience, they will be able to control the risk (Swarbrooke, Beard, Leckie, \& Pomfret, 2003). Types of activities included in the type of hard adventure trips are sky-diving, scuba diving, off-road biking, rafting, rock climbing, and cave exploration.

So based on the above definition, it can be said that hard adventure is an activity that has a high level of risk that requires experience to be carried out; the higher the risk in these activities, the more it will make the traveler encouraged to do so. There are five characteristics proposed by Swarbrooke et al (2003) that illustrate their motivation to be able to participate in adventure travel. Namely 1. uncertain results; 2. danger and rehearsal; 3 . abilities, skills and challenges; 4. gifts; and the last is 5. emotions. 
The first motivation is specific results where the traveler will be more challenged when the activities they are going to uncertain results, so they will be more motivated to carry out these activities. The second motivation is danger and risk, which is an activity that has a hazard that will create a risk whose results cannot predict, but it makes one of the motivations for the traveler. The third motivation is ability, skill, and challenge. That is, the activity chosen by the traveler is an activity that the traveler will challenge so that the abilities and skills possessed will determine what kind of activities they will choose that will increase the challenges for them. The fourth motivation is a gift in which a traveler will have certain expectations when they participate in travel adventures that have prizes such as certificates or trophies that can motivate themselves to continue to follow these activities. While the last motivation is emotion which is an adventure travel activity carried out by a traveler sometimes in an environment and situation that is different from their daily lives. The new environment can affect their emotional and mental conditions, so travelers need to prepare themselves both physically and emotionally before carrying out these activities. The characteristics that have been described above can also describe the type of hard adventure trip, where the traveler describes the challenge as the primary motivation for doing activities that are on the type of hard adventure trip.

The researcher wants to know is there a role of the Big Five Personality trait towards the tendency of hard adventure types in Indonesian tourists and which traits play the most that type of traveling. This research was conducted by replicating research on Scott \& Mowen's research (2007). The type of traveler hard adventure was chosen because of the uniqueness of individuals who like the challenges and high risks in doing so.

\subsection{Personality and traveling type}

The use of psychological factors in understanding and predicting traveler behavior has a long tradition in tourism literature (Plog, 2001). The type of traveler more defined in the role played by a traveler during a tour (Gibson \& Yiannakis, 2002). Some researchers interpret travel behavior. Differently, Madrigal calls travel behavior with travel type. In contrast, Plog calls it travel personality, then Madrigal and Kahle with holidays or travel activities and a combination of travel activities and destination selection by Frew and Shaw (Jani, 2014). Research that discusses the relationship of personality with tourism at this time is still small, so the relationship with personality elements can not be confirmed. This lack of research is somewhat unfortunate, given the many personality theories that are often used, such as the Big Five Personality that are believed to be universal and which can be used to understand travelers better and predict their travel possibilities (Scott \& Mowen, Travelers and their traits: A hierarchical model approach, 2007). Akhrani and Najib's research explains that there is a role for the big five personality traits towards the traveling soft-adventure travel type. This makes it possible for the big five personalities to be associated with other types of travel. Furthermore, other research explains that the personality type and type of trip can result in an increase in the psychological well-being of tourists (Akhrani et al, 2020).

Big Five Personalities including openness (openness to experience), conscientiousness (awareness), extraversion, agreeable (friendliness), and neuroticism, are the main factors that drive most human behavior. Some empirical studies in tourism and recreation show a relationship between Big Fie Personality and the tendency of the hard traveling adventure. Scott and Mowen (2007), for example, observed a significant relationship between big five personalities and the tendency to become an adventure traveler.

\subsection{Conceptual framework}

The purpose of the study is to look at the role of Big 5 Personality towards the tendency of Hard Adventure type. This research uses a quantitative approach with Multiple Regression analysis methods. Based on previous research, this study has the following hypotheses:

- There are roles of openness, conscientiousness, extraversion, agreeableness, and neuroticism that are simultaneously towards the tendency of the type of Hard Adventure (Ha1)

- There is a role for the Openness trait towards the tendency of the Hard Adventure type (Ha2) 
- There is a role of trait Conscientiousness towards the tendency of the Hard Adventure type (Ha3)

- There is a role for the Extraversion trait towards the tendency of the Hard Adventure type (Ha4)

- There is an Agreeableness trait role towards the tendency of Hard Adventure type (Ha5)

- There is a role of trait Neuroticism towards the tendency of the type of Hard Adventure (Ha6).

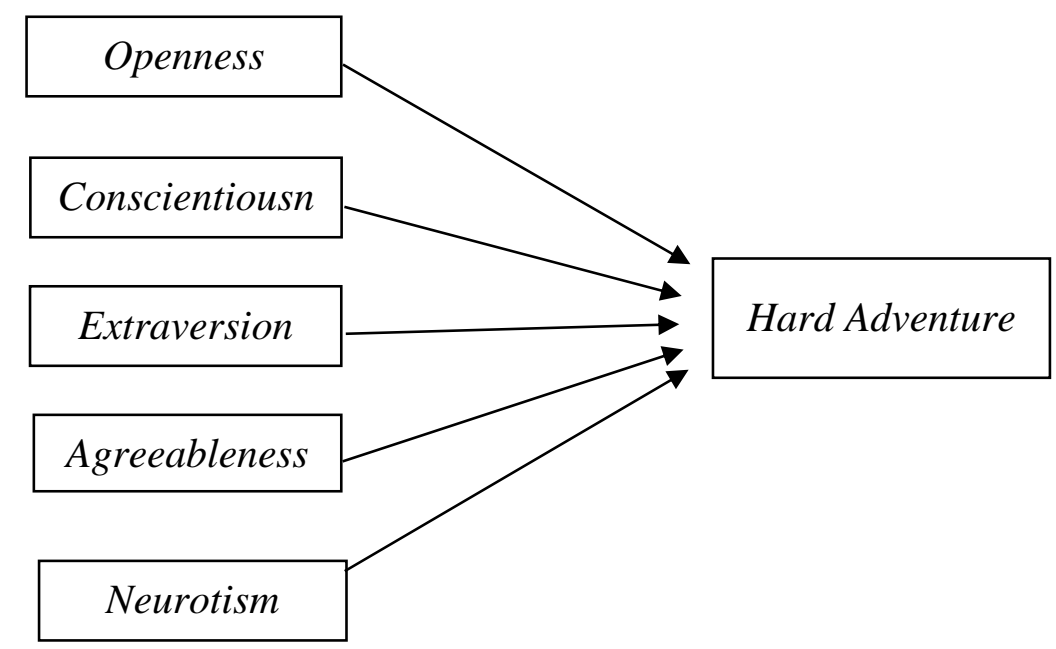

Figure 1. Conceptual framework

\section{Research methodology}

This research uses a quantitative approach, involving two variables, namely the independent variable (x) is the Big Five Personality and the dependent variable (y) is the tendency of the type of traveling hard adventure. This study aims to see the role between the variable (x), namely the Big Five Personality factor, and the variable (y), namely the tendency of the hard adventure type of traveling in Indonesian travelers. The research method used is multiple regression, where the researcher wants to explore exploratively the role between the two variables and how strong the predictor's role is for the Y variable. There are two scales in this study, namely the Big Five Inventory scale which has been trans-adapted by Ramdhani (2012). with a total of 44 items and the Traveling Type scale by Scott \& Mowen (2007) with a total of 24 items, but this study only focuses on one type of traveling, so that the researcher will only use 6 items out of the 24 total.

\subsection{Participants}

The population used in this study is Indonesian citizens who are at least 18 years old and like traveling activities. The sample of this study consisted of 1,558 Indonesian citizens who had participated in filling out questionnaires that were scattered researchers through social media.

\subsection{Measures and procedure}

The Big Five Inventory 44-item Scale is a scale developed by John O.P \& Srivastava (1990) with an initial scale by Goldberg (1990), which was then adapted by Ramdhani (Ramdhani, 2012). This study uses a 4-point Likert scale (Cronbach's $\alpha=.615$ ), with 1 indicates strongly disagree and 4 indicates strongly agree. It consists of 44 items grouped into five subscales:

a. Openness: for example, "I am a person who often gets new ideas."

b. Conscientiousness: for example, "I am the person who makes plans and then executes them."

c. Extraversion: for example, "I am a person who can inspire others."

d. Agreeableness: example, "I am a person who likes to work with others."

e. Neuroticism: for example, "I am a person who is easily tense."

High scores indicate that respondents tend to the subscale, while low scores indicate the opposite. Then the second scale is the Hard Adventure type (Scott \& Mowen, 2007) which was previously carried out by the process of adaptation regarding Beaton (2000), modification, and Focus Group Discussion 
(FGD), consisting of 6 items. Each item is worth 4 points on a Likert scale, from 1 to Strongly Disagree to an interval of 4 for Strongly Agree. This scale measures the tendency of individuals towards the type of Hard Adventure trip, with a Cronbach's $\alpha$ scale value equal to 0.814 .

The scale of the study is distributed online to Indonesian citizens who meet the research subject criteria through social media. The distribution method is shared by uploading through social media so that the subject only needs to fill in the scale of research by opening the link provided.

\subsection{Data description}

This research was carried out by distributing the questionnaire scale online by distributing it through social media. This was done because social media users who were included in the research criteria were Indonesian citizens who were at least 18 years old and liked traveling. The number of respondents who obtained the results that 1,600 subjects filled out the questionnaire, but only 1,558 subjects could be used because they met the criteria.

Table 2 shows that women tended to dominate in this study. This condition is supported by research conducted by Dwidayatour (Adiakurnia, 2018) on the needs of traveling. The results show that of 1,700 respondents, $60 \%$ of whom are women, and the remaining $40 \%$ are men (Adiakurnia, 2018).

Table 2. Participants' gender and age

\begin{tabular}{ccc}
\hline Sex & Amount & $\%$ \\
\hline Male & 239 & $15.34 \%$ \\
Female & 1319 & $84.66 \%$ \\
\hline Age & Amount & $\%$ \\
\hline $18-25$ & 1341 & $86,07 \%$ \\
$26-35$ & 159 & $10,2 \%$ \\
$36-45$ & 48 & $3,08 \%$ \\
$46-55$ & 10 & $0,64 \%$ \\
\hline
\end{tabular}

Source: data research

Researchers use age division according to the Indonesian Ministry of Health (MOH) (Santika, 2015). Based on the age category, according to the Indonesian Ministry of Health, ages 18-25 years are included in the late adolescent category. Where the individual always wants to be the centre of attention by highlighting himself, his enthusiasm and energy tend to be large so that many activities he does. This is relevant to this study, where the type of hard travel activities are draining more energy of an individual.

Table 3. Participants' job

\begin{tabular}{lll}
\hline & Amount & $\%$ \\
\hline Collage student & 943 & $61 \%$ \\
Civil Employees & 23 & $1 \%$ \\
Privat Employees & 381 & $24 \%$ \\
Entrepreneur & 95 & $6 \%$ \\
Housewife/ househusband & 39 & $3 \%$ \\
Other & 77 & $5 \%$ \\
\hline
\end{tabular}

Source: data research

Table 3 shows that the majority of subjects came from students. This result is relevant to the results in the age group of the subject where the age of 18-25 years is more dominant. As explained in Table 2, the initial age of 20 is the most dominant subject in this study. In addition, Kambuna (2013) states that there are several reasons why students are the right time to travel. The loose time students have is the first reason students have a long time off compared to students or workers. Students are also more accessible and more independent in finance, compared to students, students are freer to choose the tourist destinations they will go to because that age is no longer under the supervision of their parents, besides that students are also considered to be able to manage their finances, most of which are still depending on the giving of parents. Apart from these three reasons, not being restricted by age restrictions, being more familiar with local cultural ethics, and having more connections are reasons 
why students are the right time to travel.

Table 4. Income

\begin{tabular}{lll}
\hline Range of Income (in ruphiahs) & Amount & $\%$ \\
\hline < Rp 500.000, & 495 & $32 \%$ \\
Rp 500.001, - Rp 1000.000 & 251 & $16 \%$ \\
Rp 1000.001, - Rp 2000.000 & 307 & $20 \%$ \\
Rp 2000.001, - Rp 3000.000 & 158 & $10 \%$ \\
Rp 3000.001, - Rp 5000.000 & 218 & $14 \%$ \\
> Rp 5000.000 & 129 & $8 \%$ \\
\hline
\end{tabular}

Source: data research

The results of the study are related to the results in table 4 that discusses the subjects in this study were submitted by students or students, where both types of work do not have a fixed income and only depend on parents.

Table 5. How to travel

\begin{tabular}{lcc}
\hline How to travel & Amount & $\%$ \\
\hline Solo Traveling & 229 & $14.7 \%$ \\
Group Traveling & 1226 & $78.7 \%$ \\
Open Trip & 103 & $6.6 \%$ \\
\hline
\end{tabular}

Source: data research

Table 5 above explains that of the 1,558 subjects who filled out this questionnaire, there were 229 subjects who had a self-image traveling alone with a percentage of $14.7 \%$, then there were 1,226 subjects who had a self-image traveling with a group he knew with a percentage of $78.7 \%$, while for subjects with self-images traveling in an open trip, there were 103 subjects with a percentage of $6.6 \%$. Through these results, it is known that this study was dominated by subjects with a tendency to travel in groups with people they knew.

If this traveling picture is associated with the majority of subjects who are women, then there are different results from the results of a survey conducted by TripAdvisor. The survey revealed that women in Southeast Asia are starting to like independent travel or traveling alone. Another survey conducted by Woman and the WorldTravel with 600 women from Singapore, Malaysia, Thailand and Indonesia, found that $80 \%$ of the main reasons women travel unaccompanied by friends or family is because they are able to do whatever they want without worrying about anything. other. In addition, $75 \%$ said that those who traveled alone were able to change themselves to be more confident and able to learn about themselves. This survey also found that two out of five women $(41 \%)$ also travel with their female friends, bonding due to women being a motivating factor to travel with other women (Hidayat, 2014). Thus, even though there are differences between the results of the study and the several surveys that have been conducted, travel with known friends, especially women, is also in demand.

Table 6. Travel Planning

\begin{tabular}{lcc}
\hline & Amount & $\%$ \\
\hline Self-planned accommodation and destination & 1427 & $91.6 \%$ \\
Use the services of travel agency & 131 & $8.4 \%$ \\
\hline Source: data research & &
\end{tabular}

Table 6 explains that this study was dominated by subjects who chose to plan their tour details. This can be related to the results from Tables 3 and 4, where students with an income below Rp. 500.000 dominate the subjects in this study and adjusted to the budget that owned. 


\subsection{Categorization}

Table 7. Variable categorization

\begin{tabular}{cccc}
\hline Variable & Value Decisions & Categorization & \\
& & & \\
& & & \\
\hline Openness & $\mathrm{X}<20$ & Low & $0.5 \%$ \\
& $20 \leq \mathrm{X}<30$ & Medium & \\
Conscientiousness & $30 \leq \mathrm{X}$ & High & \\
& $\mathrm{X}<18$ & Low & $0.3 \%$ \\
& $18 \leq \mathrm{X}<27$ & Medium & \\
Extraversion & $27 \leq \mathrm{X}$ & High & \multirow{2}{*}{$0.9 \%$} \\
& $\mathrm{X}<16$ & Low & \\
Agreeableness & $16 \leq \mathrm{X}<24$ & Medium & \\
& $24 \leq \mathrm{X}$ & High & \\
& $\mathrm{X}<18$ & Low & $0.3 \%$ \\
Neuroticism & $18 \leq \mathrm{X}<27$ & Medium & \\
& $27 \leq \mathrm{X}$ & High & \\
& $\mathrm{X}<16$ & Low & $142 \%$ \\
Hard Adventure & $16 \leq \mathrm{X}<24$ & Medium & \\
& $24 \leq \mathrm{X}$ & High & \\
& $\mathrm{X}<11$ & Low & $10 \%$ \\
& $11 \leq \mathrm{X}<19$ & Medium & \\
& $19 \leq \mathrm{X}$ & High & \\
\hline
\end{tabular}

Source: data research

Table 7 shows that the majority of respondents are in the categorization while each trait of the big 5 personalities is except in the agreeableness trait. The majority of respondents from this study had a high level of agreeableness. Relevant to the data in the previous table that the majority of subjects like to travel with groups. This result also matches the characteristics found in the trait agreeableness, such as avoiding conflict and prioritizing mutual agreements with others (Wulandari \& Rehulina, 2013).

The results will also be aligned with the results in table 7, where subjects prefer to plan their traveling activities to mutually agreed. The results also indicate that the subjects in this study are in the medium category in the hard adventure variable. This relates to the risks that also present in the activity. Individu who like this activity like to do challenging things, risk factors such as safety remain one of the things to be considered.

\section{Results and discussions}

\subsection{Simultaneous Test}

Table 8 . F test result

\begin{tabular}{|c|c|c|c|c|c|}
\hline Model & Sum of Squares & $\begin{array}{l}\text { Anova } \\
\text { df }\end{array}$ & Mean Square & $\mathrm{F}$ & Sig. \\
\hline Regression & 2186.898 & 5 & 437.380 & 25.442 & .000 \\
\hline Residual & 26701.615 & 1552 & 17.205 & & \\
\hline Total & 28888.513 & 1557 & & & \\
\hline
\end{tabular}

The probability value $f$ arithmetic (sig.) In table 8 above shows the value of 0.000 , which is smaller than the significance level of 0.05 , so it can be concluded that the big five personalities as an independent variable simultaneously has a role on the type of hard adventure as a dependent variable and can simultaneously prove the major hypothesis or Hal in this study.

\subsection{T-test}

The t-test is used to see the role of trait partially, namely openness, conscientiousness, extraversion, agreeableness and neuroticism to hard adventure. Following are the results of testing the role of each trait partially. Following are the results of testing the role of each trait partially: 
Table 3. T-test result

\begin{tabular}{lcc}
\hline \multicolumn{1}{c}{ Trait } & $\mathrm{t}$ & Sig. \\
\hline Openness & 0.140 & .000 \\
Conscientiousness & -0.057 & .055 \\
Extraversion & 0.124 & .000 \\
Agreeableness & 0.013 & .657 \\
Neuroticism & -0.173 & .000 \\
\hline
\end{tabular}

Source: data research

Based on the results of the t-test with Multiple-Regression analysis shown in the table above, it shows that:

Trait openness (X1), extraversion (X3), and neuroticism (X5) have a value of $p<0.05$ so that it can be concluded that openness, extraversion, and neuroticism partially have a significant role on the tendency of hard adventure. Trait conscientiousness (X2) and agreeableness (X4) have a value of $p>0.05$, so that it can be concluded that conscientiousness and agreeableness partially do not have a significant role in the tendency of hard adventure.

Then, to see the trait that has the most significant role in the type of hard adventure can be seen from the results of the coefficients beta on each trait. Trait openness has a positive value of 0.140 , where the value is the highest value among others, so that trait openness has the most significant role in the type of hard adventure.

\subsection{Coefficient determination}

Table 40. Determinant Coefficient result

\begin{tabular}{ccccc}
\hline Model & $\mathrm{R}$ & $\mathrm{R}$ Square & $\begin{array}{c}\text { Model Summary } \\
\text { Adjusted R Square }\end{array}$ & Std. Error of the Estimate \\
\hline 1 &, $275^{\mathrm{a}}$ &, 076 &, 073 & 4,148 \\
\hline
\end{tabular}

*Predictors: Neuroticism, Extraversion, Openness, Agreeableness, Conscientiousness

*Dependent Variable: Luxury-Travel

$\mathrm{R}$ Square value shows how big the role of the big 5 personality variable as a whole to the Hard Adventure tendency, which is equal to 0.076 or $7.6 \%$, meaning that in determining the type of trip to be chosen. In this case, it is a hard adventure, big five personalities as a type of personality only account for $7.6 \%$, while the rest can be influenced by other factors not examined.

\subsection{Findings and discussions}

There are six objectives in this study. The first objective is to find out the role of the big five personalities simultaneously to the tendency of hard adventure. The other five goals are to find out the role of the big five personalities partially or separately according to the five traits available, i.e. openness, conscientiousness, extraversion, agreeableness, and neuroticism, to hard adventure.

The results showed that simultaneous big five personalities had a role of $7.6 \%$ towards the tendency of hard adventure types, so Hal is proven in this study. This result is in accordance with the results of previous research by Akhrani et al., which stated that the personality type would have a role in the type of traveling of tourists. Compared with this study, of the five personality traits in the big five personality traits, two traits do not partially play a role in the type of hard travel, namely conscientiousness and agreeableness. Whereas partially, the proven hypothesis is that only trait openness and extraversion play a significant and positively correlated role. Trait neuroticism plays a significant and negatively correlated role. Trait openness shows a positive role with the highest value on the tendency of hard adventure, meaning that the higher the individual tends towards trait openness, then the tendency of these individuals towards the type of hard adventure trip will also be higher.

These results are relevant to the results of research conducted by Jani. Individuals with high trait openness such as openness to new things tend to have a boater travel personality or things related to attractive activities to water, wherein activities. It will be found many unexpected things such as very 
rocky areas or so following it. The hard adventure itself has several activities related to water, such as rafting and scuba (Jani, 2014). Then Schneider and Vogt also said that only openness influenced the hard adventure among the five traits in big five personalities (Schneider \& Vogt, 2012). When traveling, individuals with this trait tend to like the type of hard adventure because the higher the challenges and risks they have, the more they will desire to do so.

Then, the second trait that also has a decisive role in hard adventure is extraversion. Individuals with this trait show the level of pleasure towards a relationship with others, so activities that involve many people will tend to be liked by individuals with this trait. Jani also found that individuals with high extroversion tend to travel trekker personality trails in places such as mountains and forests that will indeed intersect with a variety of individuals (Jani, 2014). When carrying out activities that are full of risks, people tend to help each other because of these conditions so that individuals with this trait will not experience difficulties communicating with others when carrying out these activities.

Trait neuroticism also has a role in the type of hard adventure, but that role is negative. The results show that this trait has a high negative role on the hard adventure. Individuals with trait neuroticism will avoid doing activities contained in this type because of the many risks that can occur when carrying out these activities. Individuals who have high trait neuroticism, such as being very careful in doing many activities, will tend to choose common destinations as one way to avoid the risks that will occur (Plog, $\underline{2001)}$.

The results in this study are also strengthened by facets that describe trait neuroticism, according to John \& Srivastava facets of trait neuroticism, which are anxiety, depression, shyness, and lack of selfconfidence (Wulandari \& Rehulina, 2013). Therefore it can be interpreted that the lower individual with trait neuroticism or individuals who do not have anxiety in doing many activities. The desire to do activities on the type of hard adventure will be higher, while traits that do not have a significant role in the type of hard adventure travel are trait conscientiousness and agreeableness.

Individuals with high levels of agreeableness are described as people who easily trust others, are generous, easy to accept, always give in, avoid conflict and are kind (Feist \& Feist, 2009). These results will be appropriate because the types of activities contained in the type of hard adventure are several types of activities carried out by individuals, such as sky diving and scuba diving, which before carrying out these activities requires decision making that must take alone. So that individuals with the agreeableness trait in decision making tend to consider and require the opinions of others, then activities on this type of hard adventure will not be appropriate.

Finally, trait conscientiousness is described by careful characteristics in making decisions, reliable, orderly, and responsible (Friedman \& Schustack, 2006). By looking at the high risks possessed by these characteristics, individuals with this trait will think a lot about all conditions and circumstances they will face, especially when the individual has no experience in carrying out these activities. This trait will tend to be incompatible with activities contained in the type of hard adventure trip.

\section{Conslusion}

Based on the explanation above, it can be concluded that the openness trait is the trait that has the most significant role in the type of hard adventure trip from the five traits found in the big five personalities. It can be interpreted that individuals who have a high tendency to openness will tend to choose to carry out new activities, challenge themselves, and meet with various people. Related to research conducted by $\underline{S c o t}$ and Mowen as research replicated by researchers, the results contained in the study differ from the results found by researchers, wherein the Scot and Mowen research results show that the trait of agreeableness which has a role on the hard adventure, where togetherness with friends is a more important thing than the adventure itself. 


\section{Recommendation}

- Based on the magnitude of the role generated in this study, there are still other factors that can influence traveler's decision making to choose the traveling type, so that these other factors are expected to explore more.

- For tourism management, such as tourist site service owners or government agencies engaged in tourism, this research can be a reference in the development of tourist attractions marketing by taking into account visitors' personality types.

- Marketing strategies may consider trait openness, extraversion, and neuroticism as traits that affect the type of hard adventure in advertisements installed and the facilities offered.

- The owner of the tour service can also provide facilities or tourist areas that remain in the hard adventure type, which can make enjoy individuals with trait conscientiousness and agreeableness who do not have a role in a hard adventure such as offering security with the help of instructors.

\section{References}

Akhrani, L.A., Alhad, M.A., Najib, A., Almira, H., Maulida, S.A., Dewi, C.F., and Yolandakhrani, C. (2020). Hallo traveler, how happy are you? Psychological well-being traveler ditinjau dari bigfive personality dan traveling type. JIPT (Jurnal Ilmiah Psikologi Terapan), 8(2), 160-176.

Akhrani, L.A. \& Najib, A. (2020). Tell me who you are and i will tell you where to go: Examining the role of big five personality in soft-adventure traveling type. GeoJournal of Tourism and Geosites, 32(4), 1299-1303. https://doi.org/10.30892/gtg.32416-572

Adiakurnia, M. I. (2018, April 14). Catat! Inilah tren traveling milenial tahun 2018. Retrieved Maret 5, 2019, from Kompas.com: https://travel.kompas.com/read/2018/04/14/150100027/catat-inilahtren-traveling-milenial-tahun-2018

Beaton, D., Bombardier, C., Guillemin, F., \& Ferraz, M. (2000). Guidelines for the process of crosscultural adaptation of self-report measures. SPINE, 24(24), 3186-3191. http://dx.doi.org/10.1097/00007632-200012150-00014

Corr, P. J., \& Matthews, G. (2009). The Cambridge handbook of personality psychology. New York: Cambridge University Press.

Ewert, A. (1987). Research in outdoor adventure: overview and analysis. The bradford papers anual, II, 15-28.

Feist, J., \& Feist, G. J. (2009). Theories of personality. United States: The McGraw-Hill Companies.

Friedman, H., \& Schustack, M. (2006). Kepribadian teori klasik dan riset modern. (Edisi ketiga jilid 1). Jakarta: Erlangga.

Gibson, H., \& Yiannakis, A. (2002). Tourist roles needs and the lifecourse. Pergamon, 358-383.

Goldberg, L.R. (1990). An alternative "description of personality": The Big-Five factor structure. Journal of personality and social psychology, 59(6), 1216

Hidayat, F. (2014, Mei 13). Survei : Perempuan lebih suka traveling sendiri. Retrieved Maret 5, 2019, from BeritaSatu: https://www.beritasatu.com/food-travel/183674-survei-perempuan-lebih-sukatraveling-sendiri.html

Jani, D. (2014). Relating travel personality to Big Five Factors of personality. Tourism, 62(4), 347-359.

John, O., \& Srivastava, S. (1990). The big-five trait taxonomy : History, measurement, and theoretical perspectives. Handbook of personality: Theory and research, 2, 102-138.

Kambuna, D. (2013). Perbedaan backpacker, solo traveler, dan conventional traveler. Retrieved from Meanwhile Traveler. https://www.meanwhileunme.com/2013/05/perbedaan-backpacker-solotraveler-dan.html

Kurniawan, I. (2015, September 19). E-paper. Retrieved Januari 6, 2019, from Harian Ekonomi Neraca: http://www.neraca.co.id/article/58831/berlibur-sudah-menjadi-kebutuhan-primer

Mill, R. C. (2009). Tourism, the international business. Zurich: Jacobs Foundation.

Pertiwi, N. L. (2011, Maret 30). Wisata alam semakin diminati wisatawan. Retrieved Januari 18, 2019, https://sains.kompas.com/read/2011/03/30/2002192/wisata.alam.semakin.diminati.wisatawan

Pervin, L., Cervone, D., \& John, O. (2010). Psikologi kepribadian teori dan penelitian. (Edisi kesembilan). Jakarta: Kencana.

Plog, S. (2001). Why destination area rise and fall in popularity. Travelers' Psychographics, 42, $13-$ 24.http://dx.doi.org/10.1016/S0010-8804(01)81020-X 
Ramdhani, N. (2012). Adaptasi bahasa dan budaya inventori big five. Jurnal Psikologi, 39(2), 189-207.

Santika, I. G. (2015). Hubungan indeks massa tubuh (IMT) dan umur terhadap daya tahan umum (kardiovaskuler) mahasiswa putra semester II kelasa fakultas pendidikan olahraga dan kesehatan ikip pgri bali tahun 2014. Jurnal pendidikan kesehatan rekreasi. Volume 1, 42-47.

Schneider, P. P., \& Vogt, C. A. (2012). Applying the 3M model of personality and motivation to adventure travelers. Journal of travel research, 51(6), 704-716. http://doi: $10.1177 / 0047287512451134$

Schott, C. (2007). Selling adventure tourism: a Distribution channels perspective. International Journal of Tourism Research, 9, 257-274. http://doi: 10.1002/jtr.610

Scott, K., \& Mowen, J. C. (2007). Travelers and their traits: A hierarchical model approach. Consumer Behaviour, 6, 146-157. http://doi: 10.1002/cb.214

Swarbrooke, J., Beard, C., Leckie, S., \& Pomfret, G. (2003). Adventure tourism the new frontier. Oxford: Butterworth Heinemann.

Wulandari, A., \& Rehulina, M. (2013). Hubungan antara Lima Faktor Kepribadian (The Big Five Personality) dengan Makna Hidup pada Orang dengan Human Immunodefciency Virus. Jurnal Psikologi Klinis dan Kesehatan Mental, 2(1), 41-47. 